\title{
Fat deposition of broiler chickens fed a high-fat diet contained Sauropus androgynus leaf extract plus turmeric powder
}

\author{
K. Kususiyah ${ }^{1, *}$, U. Santoso ${ }^{1}$, Y. Fenita ${ }^{1}$, A. M. H. Putranto ${ }^{2}$ and S. Suharyanto ${ }^{1}$ \\ ${ }^{1}$ Department of Animal Science, Faculty of Agriculture, Bengkulu University, \\ Kota Bengkulu 38371A - Indonesia. \\ ${ }^{2}$ Department of Chemistry, Faculty of Mathetamics and Natural Science, \\ Bengkulu University, Kota Bengkulu 38371A, Indonesia. \\ *Corresponding E-mail: kususiyah@unib.ac.id
}

Received July 02, 2019; Accepted November 04, 2019

\begin{abstract}
ABSTRAK
Rancangan acak lengkap faktorial digunakan untuk menganalisis pengaruh ekstrak daun katuk (EDK) plus tepung kunyit (TK) terhadap deposisi lemak pada ayam broiler yang diberi pakan tinggi lemak. Seratus lima puluh ayam broiler berumur 21 hari digunakan dalam penelitian ini. Faktor pertama adalah sumber lemak (6\% lemak sapi dan 6\% minyak sawit), dan faktor kedua adalah EDK plus TK $0 \mathrm{~g}$ EDK plus $0 \mathrm{~g}$ TK (G1), $9 \mathrm{~g}$ EDK plus 0,5 g TK (G2), $18 \mathrm{~g}$ EDK plus 0,5 g TK (G3), $9 \mathrm{~g}$ EDK plus $1 \mathrm{~g}$ TK (G4), $18 \mathrm{~g}$ EDK plus $1 \mathrm{~g}$ TK (G5)]. Suplementasi EDK plus TK mempengaruhi kolesterol, asam laurat, asam miristat, asam palmitat, asam stearat dan asam eikosapentaenoat daging $(\mathrm{p}<0,01)$. Sumber lemak mempengaruhi lemak, kolesterol, asam laurat, asam miristat, asam palmitat, asam stearat dan asam eikosapentaenoat daging $(\mathrm{p}<0,01)$. Terdapat interaksi yang signifikan antara dua faktor pada kadar lemak, kolesterol, asam laurat, asam palmitat, asam stearat, dan asam eicosapentaenoat daging. Kesimpulannya, suplementasi $18 \mathrm{~g}$ EDK plus $1 \mathrm{~g}$ TK pada pakan berlemak tinggi menghasilkan asam stearat yang lebih rendah, tetapi menghasilkan asam eikosapentaenoat yang lebih tinggi. Suplementasi EDK plus TK pada pakan tinggi lemak menurunkan kadar kolesterol daging dan mengubah komposisi asam lemak.
\end{abstract}

Kata kunci: Sauropus androgynus, tepung kunyit, penimbunan lemak, asam lemak, broiler

\section{ABSTRACT}

A factorial design was used to analyze the influence of Sauropus androgynus leaf extract (SALE) and turmeric powder (TP) on fat deposition in broilers fed high-fat diet. The first factor was the source of fat ( $6 \%$ beef fat and $6 \%$ palm oil), and the second factor was SALE plus TP [0 g SALE plus $0 \mathrm{~g}$ TP (G1), 9 g SALE plus $0.5 \mathrm{~g}$ TP (G2), $18 \mathrm{~g}$ SALE plus $0.5 \mathrm{~g}$ TP (G3), $9 \mathrm{~g}$ SALE plus $1 \mathrm{~g}$ TP (G4), $18 \mathrm{~g}$ SALE plus $1 \mathrm{~g}$ TP (G5)]. SALE plus TP affected cholesterol, lauric acid, myristic acid, palmitic acid, stearic acid and eicosapentaenoic acid contents $(\mathrm{p}<0.01)$. Fat sources affected fat, cholesterol, lauric acid, myristic acid, palmitic acid, stearic acid and eicosapentaenoic acid $(p<0.01)$. There was a significant interaction between the two factors on fat, cholesterol, lauric acid, palmitic acid, stearic acid, and eicosapentaenoic acid contents. In conclusion, $18 \mathrm{~g}$ SALE plus $1 \mathrm{~g}$ TP supplementation to high-fat diet resulted in lower stearic acid, but it resulted in higher eicosapentaenoic acid. Supplementation of SALE plus TP to a high-fat diet lowered cholesterol content and changed fatty acids composition.

Keywords: Sauropus androgynus,turmeric powder,fat deposition,fatty acid, broilers 


\section{INTRODUCTION}

Dietary fats are important in the diet of broiler chickens as a source of energy and essential fatty acids, and these fats also enhance the palatability of the diet and the absorption of fat-soluble vitamins. Therefore, feeding a high-fat diet may be useful in meeting the energy requirements of broiler chickens. Moreover, feeding a high-fat diet improves growth efficiency because of enhanced feed efficiency (Breslin et al., 2010). A high-fat diet also causes longer feed retention in the gastrointestinal tract; and thus, improves nutritional digestion and absorption (Fouad and El-Senousey, 2014). However, feeding a high-fat diet may produce low quality meats because of high-fat deposition (Fouad and ElSenousey, 2014). In addition, consuming high-fat meats may induce obesity, hypercholesterolemia, atherosclerosis, coronary heart disease, stroke (Winter et al., 2008; Pijlman et al., 2010). To induce high fat deposition broiler chickens could be fed fat sources range from $4-8 \%$ (Baiao and Lara, 2005).

To minimize negative effects, a high-fat diet should be balanced by feeding supplements that could reduce fat deposition (Santoso et al., 2000). Sauropus androgynus leaf is rich in palmitic acid, linolenic acid, chlorophyll, alkaloids and benzoic acid (Samad et al., 2014), $\beta$-carotene and glutamic acid (Santoso et al., 2015 ), flavonoids and phenols (Santoso et al., 2017). These compounds are detected to have antilipid and antioxidant properties. Sauropus androgynus leaf extract (SALE) reduced the cholesterol and triglyceride content of meats, and the fat deposition in poultry fed a normal-fat diet (Santoso and Sartini, 2001; Santoso et al., 2005; Santoso et al., 2010 a 2013). SALE could be provided at 9-18 $\mathrm{g} / \mathrm{kg}$ (Santoso et al., 2005; Santoso et al., 2010 ) to reduce fat deposition in broiler chickens. However, no research is conducted in order to analyze the influence of Sauropus androgynus leaf on fat deposition in broiler chickens fed a high-fat diet.

To increase the ability of SALE in decreasing fat deposition it is necessary to add other antilipid ingredients. One potential ingredient is turmeric. Turmeric has potential to reduce blood triglyceride concentration in broiler chickens (Nouzarian et al., 2011; Asai and Miyazawa. 2001.), enhances low-density lipoprotein receptors, hemeoxygenase and cholesterol 7 a-hydroxylase (Yiu et al., 2011).
Lone et al. (2014) found that curcumin (an active compound in turmeric) inhibite adipogenesis and induce the brown fat-like phenotype. Curcumin also increase fatty acids oxidation and reduce fatty acids esterification, resulting in net catabolism in adipose tissue (Ejaz et al., 2009). Supplementation of turmeric powder at $1 \mathrm{~g} / \mathrm{kg}$ diet is adequate for reducing fat deposition in broiler chickens (Samarasinghe et al., 2003). Therefore, the influence of SALE-TP supplementation on fat deposition in broiler chickens fed a high-fat diet was studied. It was hypotesized that supplementation of SALE-TP mixture to a high-fat diet would reduce fat deposition in broiler chickens.

\section{MATERIALS AND METHODS}

\section{The Extraction of Sauropus andrognus Leaf}

The leaves were extracted according to Santoso et al. (2005), whereas turmeric powder was obtained from the traditional market. Basal diet contained 19,64\% crude protein and 3,215 $\mathrm{kcal} \mathrm{ME} / \mathrm{kg}$ diet (Santoso et al., 2010b).

\section{Animals and Diets}

Broilers (Arbor Acres) used in this study were maintained according to Santoso et al. (2015a) and Santoso (2015b). One hundred and fifty broiler chickens aged 21 days were weighed and selected, and were distributed into ten treatment groups of 15 broiler chickens each. The present research was arranged as completely randomized factorial design $(2 \times 5)$ in which two dietary fat sources, namely $6 \%$ beef tallow (BT) and $6 \%$ palm oil (PO), and five mixtures of SALE plus TP, namely $0 \mathrm{~g}$ SALE plus $0 \mathrm{~g}$ TP (G1), $9 \mathrm{~g}$ SALE plus $0.5 \mathrm{~g}$ TP (G2), $18 \mathrm{~g}$ SALE plus $0.5 \mathrm{~g}$ TP (G3), $9 \mathrm{~g}$ SALE plus $1 \mathrm{~g}$ TP (G4), and $18 \mathrm{~g}$ SALE plus $1 \mathrm{~g}$ TP (G5) were evaluated. Body weight of broilers were measured weekly and feed intakes were recorded daily. To induce high fat deposition broiler chickens could be fed fat sources range from 4-8\% (Baiao and Lara, 2005), whereas SALE could be provided at 9-18 $\mathrm{g} / \mathrm{kg}$ (Santoso et al., 2005; Santoso et al., 2010). Supplementation of turmeric powder at $1 \mathrm{~g} / \mathrm{kg}$ diet was adequate to lower fat deposition in broiler chickens (Samarasinghe et al., 2003). Drinking water and diets were given ad libitum.

\section{Sampling and Laboratory Analysis}

Four broiler chickens aged 42 days in each group were slaughtered. After that, the abdominal 
and neck fat were removed and weighed. Fatty liver score was measured by comparing liver color with liver color standard from 1-5. Furthermore, leg meats were then removed and stored at $-30^{\circ} \mathrm{C}$. Fat and cholesterol contents were measured by the method of AOAC (1990), where as fatty acid composition was measured by the method of Almeida et al. (2006).

\section{Data Analysis}

All data were subjected to analysis of variance as a $2 \times 5$ factorial arrangement of dietary treatments with dietary fat sources and SALE-TP mixtureas main effects. If it was significantly different, the data were then further tested using Duncan's Multiple Range Test.

\section{RESULTS AND DISCUSSION}

\section{Fat Deposition and Salmonella sp.}

Dietary fat sources did not influence abdominal fat, neck fat or fatty liver score $(\mathrm{P}>0.05)$, but it influenced meat fat or cholesterol content $(P<0.01)$ (Table 1). It was found that beeftallow diet resulted in higher the contents of fat or cholesterol in meats. The addition of SALE-TP mixture did not influence abdominal fat, neck fat, fatty liver score or fat content $(\mathrm{P}>0.05)$, but it reduced cholesterol content $(\mathrm{P}<0.01)$ (Table 2$)$. SALE-TP inclusion significantly reduced meat cholesterol content in G4 and G5 $(\mathrm{P}<0.01)$. No interaction was found in abdominal fat, neck fat or fatty liver score, whereas interaction was found in meat fat $(\mathrm{P}<0.05)$ or cholesterol $(\mathrm{P}<0.01)$ contents (Table 3). Meat fat contents in BT.G4, BT.G5, PO.G1, PO.G2, PO.G3, PO.G4 and PO.G5 were significantly lower than BT.G1 $(\mathrm{p}<0.05)$, whereas meat cholesterol contents in BT.G3, BT.G4, BT.G5, PO.G1, PO.G2, PO.G3, PO.G4 or PO.G5 were significantly lower than BT.G1 and BT.G2 $(\mathrm{P}<0.01)$. No Salmonella $s p$. was found in broiler meats of all treatment groups.

The present study showed that a high-fat diet caused fatty liver disease as indicated by a high fatty liver score. A high-fat diet produced fatty liver disease, obesity and metabolic syndrome in mice (Bose et al., 2008). Thus, SALE-TP supplementationis unable to prevent the occurrence of fatty liver disease.

Beef-tallow diet resulted in similar abdominal fat and neck fat deposition to palm-oil diet, which is in contrary to Smink et al. (2010). SALE-TP did not reduce fatty liver score, the fat deposition in abdomen or neck, and meat fat content.

The reduction of cholesterol content by SALE-TP supplementation might be caused by active compounds such as methylpyroglutamate, flavonoid, tannin, saponin (Warditiani et al., 2016) alkaloid (Santoso et al., 2010 ${ }^{\mathrm{c}}$ ) that present in Sauropus androgynus leaf and curcumin (Kim and Kim, 2010). Kamboh and Zhu (2013) reported that the inclusion of flavonoid reduced cholesterol content in serum, liver and breast meat. Afrose et al. (2010) reported that supplementation of $25 \mathrm{mg}$ saponin reduced meat cholesterol content in breast and thigh of broiler chickens. Kim and Kim (2010) found that curcumin increased cholesterol 7a-hydroxylase (CYP7A1) gene expression, and Asai and Miyazawa (2001) found curcumin stimulated hepatic acyl-CoA oxidase activity, whereas FAS activity was not influenced. This suggested that curcumin influences fatty acid catabolism rather than fatty acid synthesis in the liver.

A high beef-tallow diet feeding produced a higher meat fat or cholesterol content a than high palm-oil diet feeding. Beef-tallow relatively contains similar saturated fatty acids to palm oil, but it has lower PUFA than palm-oil. The fatty acids composition of beef-tallow was as follows: myristic acid $3.7 \%$, palmitic acid $21.5 \%$, stearic acid $17.7 \%$ (saturated fatty acid), oleic acid $41.4 \%$ (monounsaturated fatty acids), linoleic acid 3.1\% and linolenic acid $0.6 \%$ (PUFA) (Ramos et al., 2009), whereas the composition of fatty acids of palmoil was as follows: myristic acid $0.7 \%$, palmitic acid $36.7 \%$, stearic acid $6.6 \%$, oleic acid $46.1 \%$, linoleic acid $8.6 \%$, linolenic $0.3 \%$ (Chowdhury et al., 2007. Saturated fat source increase fat, cholesterol and triglyceride contents in comparison with unsaturated fat source (Katun et al., 2018; Smink et al., 2010).

The present results found that there was interaction between SALE-TP mixture and dietary fat sources on meat fat or cholesterol content. It is unknown that why this feed supplement decreased fat or cholesterol contents of meats in broiler chickens fed a high-beef tallow diet, but it did not reduce them in broiler chickens fed a high palmoil diet. Feeding beef-tallow diet produced higher cholesterol levels as compared to palm-oil diet (Table 1). It is suspected that broiler chickens which had higher meat cholesterol contents are more easily modified. Low cholesterol content in the body is difficult to be reduced by a diet due to partly related to the amount of cholesterol needed 
Table 1. The Effect of Dietary Fat Sources (Main Effect) on Fat Deposition of Broiler Chickens

\begin{tabular}{lcccc}
\hline Variables & $6 \%$ BT & $6 \%$ PO & SD & P \\
\hline Fatty liver score & 4.42 & 4.22 & 0.22 & $\mathrm{NS}$ \\
Abdominal fat $(\mathrm{g} / 100 \mathrm{~g})$ & 2.63 & 2.45 & 0.28 & $\mathrm{NS}$ \\
Neck fat $(\mathrm{g} / 100 \mathrm{~g})$ & 0.66 & 0.62 & 0.07 & $\mathrm{NS}$ \\
Meat & & & & \\
Fat $(\%)$ & 3.02 & 2.51 & 0.31 & $\mathrm{P}<0.01$ \\
Cholesterol $(\mathrm{mg} / 100 \mathrm{mg})$ & 1.56 & 1.38 & 0.11 & $\mathrm{P}<0.01$ \\
\hline
\end{tabular}

$\mathrm{BT}=$ Beef Tallow, $\mathrm{PO}=$ Palm Oil, $\mathrm{NS}=$ non significant.

Table 2. The Effect of Sauropus androgynus LeafExtract Plus Turmeric Powder (Main Effect) Supplementation on Fat Deposition of Broiler Chickens

\begin{tabular}{lccccccc}
\hline Variables & G1 & G2 & G3 & G4 & G5 & SD & P \\
\hline Fatty liver score & 4.06 & 4.66 & 4.47 & 4.28 & 4.15 & 0.36 & NS \\
Abdominal fat, \% & 2.54 & 2.58 & 2.95 & 2.24 & 2.35 & 0.28 & NS \\
Neck fat, \% & 0.77 & 0.70 & 0.69 & 0.47 & 0.57 & 0.14 & $\mathrm{NS}$ \\
Meat & & & & & & & \\
Fat , \% & 3.00 & 2.70 & 2.80 & 2.70 & 2.55 & 0.43 & $\mathrm{NS}$ \\
$\begin{array}{l}\text { Cholesterol (mg/100 } \\
\text { mg) }\end{array}$ & $1.57^{\mathrm{a}}$ & $1.60^{\mathrm{a}}$ & $1.50^{\mathrm{a}}$ & $1.31^{\mathrm{b}}$ & $1.31^{\mathrm{b}}$ & 0.28 & $\mathrm{P}<0.01$ \\
\hline
\end{tabular}

G1 $=0 \mathrm{~g}$ Sauropus androgynus leaf extract (SALE) $+0 \mathrm{~g}$ turmeric powder (TP); G2 $=9 \mathrm{~g}$ SALE $+0.5 \mathrm{~g}$ TP; G3=18 g SALE + 0.5 g TP; G4=9 g SALE + 1 g TP; G5=18 g SALE + 1 g TP. NS= non significant. Means within a row not followed by the same supercripts are significantly different.

by the body. It is assumed that low cholesterol content is only enough to meet the need of cholesterol in the body, therefore it is difficult to be modified by a diet. There is cholesterol resistance in the body to modification by diet. If the amount of cholesterol in the body is in accordance with the needs, the body will tend to maintain the levels. For example, cholesterol in eggs is more difficult to be modified by diet because cholesterol in eggs is prepared for embryo development later. Wood et al. (1961) reported that laying hens were less susceptible to hypercholesterolemia induced by dietary cholesterol than were mature cockerels. Santoso (1992) found that male broilers that have lower fat content are more difficult to be modified by feed restrictions when compared to female broilers that have higher fat content.

No Salmonella $s p$. was detected in broiler meats suggested that broiler chickens were maintained in proper condition, and therefore, it resulted in Salmonella $s p$. free meats. Salmonella is a major public health burden in many countries (Atterbury et al., 2007).

\section{Meat Fatty Acid Composition}

Dietary fat sources significantly affected lauric acid, myristic acid or stearic acid $(\mathrm{P}<0.01)$, but it did not influence other fatty acids (Table 4). Feeding a beef-tallow diet resulted in lower lauric acid, but it had higher myristic acid or stearic acid as compared to feeding a palm-oil diet. SALE-TP supplementation significantly affected lauric acid, myristic acid, palmitic acid, stearic acid or 


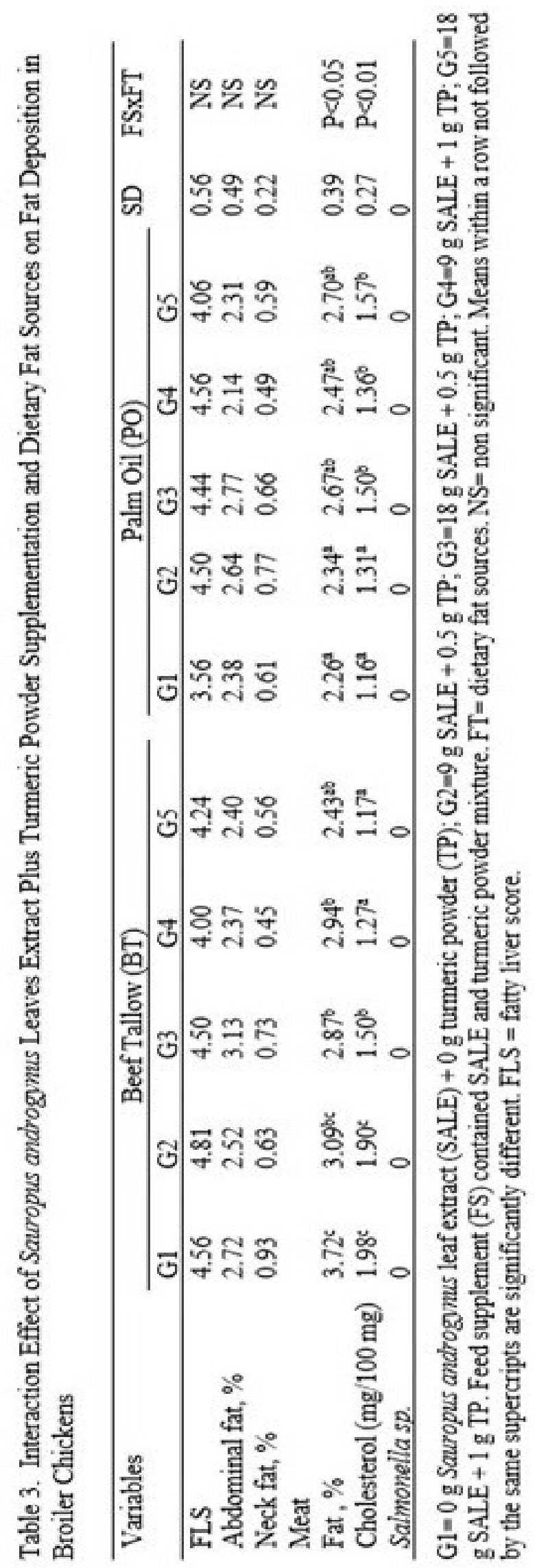


eicosapentaenoic acid $(\mathrm{P}<0.01)$, but it had no effect on oleic acid, linoleic acid, linolenic acid, docosapentaenoic acid or docosahexaenoic acid (Table 5). It was shown that lauric acid and myristic acid in G3 and P4 were higher than those in G1, G2 and G5. Furthermore, palmitic acid in
G1 was lower than in G4, but it was higher than in G2 and G3. Moreover, eicosapentaenoic acid in G1 or G2 was lower than that in G3, G4 and G5.Interaction was found in lauric acid, palmitic acid, stearic acid or eicosapentaenoic acid $(\mathrm{P}<0.01)$, but it had no interaction in other fatty

Table 4. The Effect of Dietary Fat Sources (Main Effect) on Fatty Acid Composition of Broiler Meat

\begin{tabular}{lcccc}
\hline Fatt acid (\% total fatty acid) & $6 \%$ BT & $6 \%$ PO & SD & P \\
\hline Lauric acid & 0.124 & 0.145 & 0.018 & $\mathrm{P}<0.01$ \\
Myristic acid & 0.147 & 0.09 & 0.029 & $\mathrm{P}<0.01$ \\
Palmitic acid & 9.42 & 9.57 & 0.165 & $\mathrm{NS}$ \\
Stearic acid & 2.03 & 1.775 & 0.148 & $\mathrm{P}<0.01$ \\
Oleic acid & 31.80 & 31.74 & 0.076 & $\mathrm{NS}$ \\
Linoleic acid & 22.371 & 21.539 & 0.455 & $\mathrm{NS}$ \\
Linolenic acid & 2.185 & 2.05 & 0.081 & $\mathrm{NS}$ \\
Eicosapentaenoic acid & 1.64 & 1.64 & 0.010 & $\mathrm{NS}$ \\
Docosapentaenoic acid & 1.437 & 1.311 & 0.074 & $\mathrm{NS}$ \\
Docosahexaenoic acid & 1.237 & 1.155 & 0.108 & $\mathrm{NS}$ \\
\hline
\end{tabular}

$\mathrm{BT}=$ Beef Tallow, $\mathrm{PO}=$ Palm Oil

Table 5. The Effect of Sauropus androgynusLeafExtract PlusTurmeric Powder (Main Effect)Supplementation on Fatty Acid Composition of Broiler Meat

\begin{tabular}{lccccccc}
\hline $\begin{array}{l}\text { Fatty acid (\% total fatty } \\
\text { acid) }\end{array}$ & G1 & G2 & G3 & G4 & G5 & SD & P \\
\hline Lauric acid & $0.0595^{\mathrm{a}}$ & $0.080^{\mathrm{a}}$ & $0.220^{\mathrm{b}}$ & $0.207^{\mathrm{b}}$ & $0.105^{\mathrm{a}}$ & 0.099 & $\mathrm{P}<0.01$ \\
Myristic acid & $0.0775^{\mathrm{a}}$ & $0.1105^{\mathrm{a}}$ & $0.179^{\mathrm{b}}$ & $0.149^{\mathrm{b}}$ & $0.085^{\mathrm{a}}$ & 0.057 & $\mathrm{P}<0.01$ \\
Palmitic acid & $9.505^{\mathrm{b}}$ & $8.792^{\mathrm{a}}$ & $10.095^{\mathrm{bc}}$ & $10.61^{\mathrm{c}}$ & $8.474^{\mathrm{a}}$ & 1.418 & $\mathrm{P}<0.01$ \\
Stearic acid & $1.957^{\mathrm{b}}$ & $2.118^{\mathrm{b}}$ & $2.134^{\mathrm{b}}$ & $1.966^{\mathrm{b}}$ & $1.338^{\mathrm{a}}$ & 0.468 & $\mathrm{P}<0.01$ \\
Oleic acid & 31.487 & 31.430 & 31.577 & 32.856 & 31.506 & 1.360 & $\mathrm{NS}$ \\
Linoleic acid & 23.584 & 21.854 & 20.853 & 21.793 & 21.555 & 1.127 & $\mathrm{NS}$ \\
Linolenic acid & 2.048 & 1.952 & 2.260 & 2.211 & 2.118 & 0.257 & $\mathrm{NS}$ \\
Eicosapentaenoic acid & $1.485^{\mathrm{a}}$ & $1.5^{\mathrm{a}}$ & $1.712^{\mathrm{b}}$ & $1.677^{\mathrm{b}}$ & $1.82^{\mathrm{b}}$ & 0.383 & $\mathrm{P}<0.01$ \\
Docosapentaenoic acid & 1.508 & 1.265 & 1.329 & 1.552 & 1.260 & 0.224 & $\mathrm{NS}$ \\
Docosahexaenoic acid & 1.162 & 1.106 & 1.217 & 1.435 & 1.074 & 0.194 & $\mathrm{NS}$ \\
\hline
\end{tabular}

$\mathrm{G} 1=0 \mathrm{~g}$ Sauropus androgynus leaf extract (SALE) $+0 \mathrm{~g}$ turmeric powder (TP); G2=9 g SALE $+0.5 \mathrm{~g}$ TP; $\mathrm{G} 3=18 \mathrm{~g}$ SALE $+0.5 \mathrm{~g}$ TP; G4=9 g SALE $+1 \mathrm{~g}$ TP; G5=18 g SALE + $1 \mathrm{~g}$ TP. Ns= non significant. Means within a row not followed by the same supercripts are significantly different. 


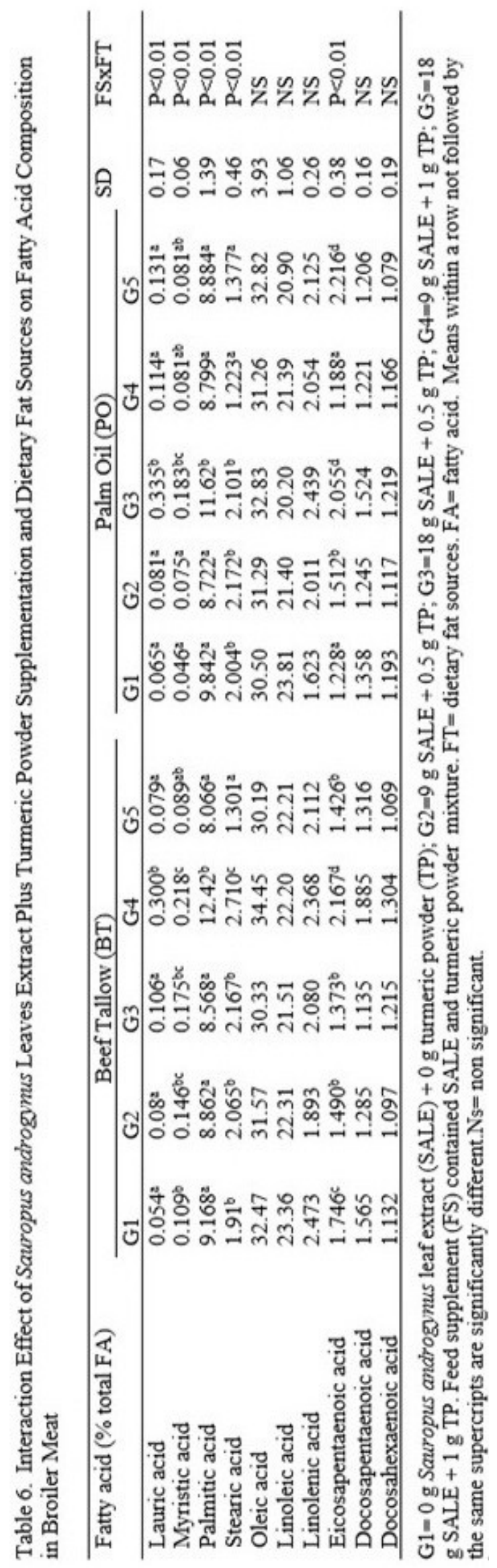


acids (Table 6). Lauric acid was higher in BT.G4 and PO.G3, and palmitic acid was higher in BT.G4 and PO.G3 as compared to other treatment groups. Furthermore, stearic acid was the lowest in BT.G5, PO.G4 and PO.G5, whereas eicopentaenoic acid was the lowest in PO.G1 and PO.G5.

The higher myristic acid and stearic acid in broiler fed high beef-tallow diet were as result from higher their contents in beef tallow as compared with palm oil (Chowdhury et al., 2007; Ramos et al., 2009). Bonoli et al. (2007) reported that feeding animal fat produced chicken meats with higher myristic acid, palmitic acid and similar lauric acid and stearic acid as compared to vegetable oil.

Sauropus androgynus leaf contains a high palmitic acid (Santoso et al., 2015a) or linolenic acid (Samad et al., 2014). However, the mixture of SALE and TP inconsistently affected palmitic acid with no effect on linolenic acid.This result is in contrary with the study of Santoso et al. (2018) who showed lower meat linolenic acid in broilers fed a diet contained 5\% Sauropus androgynus leaves. It was unknown why this mixture influenced lauric acid, myristic acid, palmitic acid, stearic acid and eicosapentaenoic acid. Lower stearic acid with higher eicosapentaenoic acid in meat of broiler chickens fed high-fat diet supplemented with $18 \mathrm{~g}$ SALE plus $1 \mathrm{~g}$ TP might be beneficial for consumers because it was known that consuming a product with higher eicosapentaenoic acid reduced the risk of cardiovascular diseases (Schacky and Harris, 2007). Curcumin inclusion would prevent the oxidation of unsaturated fatty acids in broiler meats (Khan et al., 2012).

There was significant interaction between the two factors on the lauric acid, myristic acid, palmitic acid or eicosapentaenoic acid. It was shown that supplementing $9 \mathrm{~g}$ SALE plus $1 \mathrm{~g}$ TP to $6 \%$ beef tallow diets produced meats with higher lauric acid, myristic acid, palmitic acid, stearic acid and eicosapentaenoic acid, whereas supplementing $18 \mathrm{~g}$ SALE plus $0.5 \mathrm{~g}$ TP to $6 \%$ palm oil diets produced meats with higher lauric acid, myristic acid, palmitic acid, stearic acid and eicosapentaenoic acid.

In overall, supplementation of $18 \mathrm{~g}$ SALE plus $1 \mathrm{~g}$ TP to $6 \%$ beef-tallow diet produced meats with lower cholesterol, fat and stearic acid contents. This similar mixture supplementation to $6 \%$ palm-oil diet produced meats with lower stearic acid, higher eicosapentaenoic acid, fat and cholesterol. It appears that this mixture is more useful when it is supplemented to $6 \%$ beef-tallow diet than that to $6 \%$ palm-oil diets.

\section{CONCLUSION}

Supplementation of SALE-TP to a high-fat diet reduced meat cholesterol content and changed fatty acid composition. Supplementation of $18 \mathrm{~g}$ SALE plus $1 \mathrm{~g}$ TP to a high-fat diet produced lower stearic acid and higher eicosapentaenoic acid meats. This mixture was more useful when it was supplemented to $6 \%$ beef-tallow diet than that to $6 \%$ palm-oil diet. Feeding a beef-tallow diet increased fat and cholesterol content of broiler meats. This research discovers the potential of Sauropus androgynus leaf extract plus turmeric powder for normalizing or reducing fat deposition in broiler chickens fed high-fat diet.

\section{ACKNOWLEDGMENTS}

The present experiment was supported by Directorate General of Higher Education, Ministry of National Education under contract number: 2234/H30.10.06.01/HK/2010 dated March 25, 2010. The authors are grateful to Guntur Parmonangan Purba and Dana Arie Ranggi for their assistance during the experiment. We also thank Isnani Murti, S.I.Kom for her assistance in administrative research. No any conflict of interest among the authors.

\section{REFERENCES}

Almeida, J.C. de, M.S. Perassolo, J.L. Camargo, N. Bragagnolo and J.L. Gross. 2006. Fatty acid composition and cholesterol content of beef and chicken meat in Southern Brazil.Braz. Pharm. Sci. 42:109-117.

Asai, A. and T. Miyazawa. 2001.Dietary curcuminoids prevent high-fat diet-induced lipid accumulation in rat liver and epididymal adipose tissue. J. Nutr. 131:2932-2935.

A.O.A.C. 1990. Official Methods of Analysis. Association of Official Analytical Chemist, Inc., Arlingtong, Virginia.

Afrose, S., Md.S. Hossain, T. Maki and H. Tsujii. 2010. Hypocholesterolemic response to karaya saponin and Rhodobacter capsulatus in broiler chickens. AsianAustralas. J. Anim. Sci. 23 (6):733-741.

Atterbury, R.J., M.A.P. Van Bergen, F. Ortiz, 
M.A. Lovell, J.A. Harris,A. De Boer, J.A. Wagenaar, V.M. Allen and .A. Barrow. 2007. Bacteriophage therapy to reduce Salmonella colonization of broiler chickens. Appl. Environ. Microbiol. 73: 4543-4549.

Baiao, N.C. and L.J.C. Lara. 2005. Oil and fat in broiler nutrition. Braz. J. Poultry Sci. 7: 129-141.

Bose, M., J.D. Lambert, J. Ju, K.R. Reuhl, S.A. Shapses and C.S. Yang. 2008. The major green tea polyphenol, (-)-epigallocatechin3-gallate, inhibits obesity, metabolic syndrome, and fatty liver disease in highfat-fed mice. J. Nutr. 138:1677-1683.

Breslin, W.L., K. Strohacker, K.C. Carpenter, L. Esposito and B.K. McFarlin. 2010. Weight gain in response to high-fat feeding in CD1 male mice. Lab. Anim. 44:231-237.

Chowdhury, K., L.A. Banu, S. Khan and A. Latif. 2007. Studies on the fatty acid composition of edible oil. Bangladesh J. Sci. Ind. Res. 42:311-316.

Ejaz, A., D. Wu, P. Kwan and M. Meydani. 2009. Curcumin inhibits adipogenesis in 3T3-L1 adipocytes and angiogenesis and obesity in C57/BL Mice1-3. J. Nutr. 139:1-7.

Fouad, A.M. and H.K. El-Senousey. 2014. Nutritional factors affecting abdominal fat deposition in poultry: a review. AsianAustralas. J. Anim. Sci. 27: 1057-1068.

Kamboh, A. A. and W. Y. Zhu. 2013. Effect of increasing levels of bioflavonoids in broiler feed on plasma anti-oxidative potential, lipid metabolites, and fatty acid composition of meat. Poultry Sci. 92:454461.

Khan, R.U., S. Naz, M. Javdani, D.V. Laudadio andV. Tufarelli. 2012. The use of turmeric (Cucurma longa) in poultry feed. World's Poultry Sci. J. 68:97-103.

Khatun, J., T.C. Loh, H. Akit, H.L Foo and R. Mohamad. 2018. Influence of different sources of oil on performance, meat quality, gut morphology, ileal digestibility and serum lipid profile in broilers. J. Appl. Anim. Res. 46:479-485.

Kim, M. and Y. Kim. 2010. Hypocholesterolemic effects of curcumin via up-regulation of cholesterol 7a-hydroxylase in rats fed a high fat diet. Nutr. Res. Pract. 4:191-195.

Lone, J., J.H. Choi, S.W. Kim and J.W. Yun. 2016. Curcumin induces brown fat-like phenotype in 3T3-L1 and primary white adipocytes. J. Nutr. Biochem. 27: 193-202.

Nouzarian, R., S.A. Tabeidian, M. Toghyani, G. Ghalamkari and M. Toghyani. 2011. Effect of turmeric powder on performance, carcass traits, humoral immune responses, and serum metabolites in broiler chickens. J. Anim. Feed Sci. 20:389-400.

Pijlman, A.H., R. Huijgen, S. N. Verhagen, B.P. Imholz, A.H. Liem, J. J. Kastelei, E.J. Abbink, A.F. Stalenhoef and F.L. Visseren. 2010. Evaluation of cholesterol lowering treatment of patients with familial hypercholesterolemia: a large crosssectional study in The Netherlands. Atherosclerosis. 209:189-194.

Ramos, M.J., C.M. Fernández, A. Casas, L. Rodríguez and A. Pérez. 2009. Influence of fatty acid composition of raw materials on biodiesel properties. Bioresource Technol. 100:261-268.

Samad, A.P.A., U. Santoso, M.C. Lee and F.H. Nan. 2014. Effects of dietary katuk (Sauropus androgynus L. Merr.) on growth, non-specific immune and diseases resistance against Vibrio alginolyticus infection in grouper Epinephelus coioides. Fish Shellfish Immunol. 30:582-589.

Samarasinghe, K., C. Wenk, K.F.S.T. Silva and J.M.D.M. Gunasekera. 2003. Turmeric (Curcuma longa) root powder and mannanoligosaccharides as alternatives to antibiotics in broiler chicken diets. AsianAustralas. J. Anim. Sci. 16:1495-1500.

Santoso, U. 1992. Effect ofEarly Feed Restriction on Growth and Body Composition in Broiler Chickens. Master Thesis, Gifu University, Gifu, Japan.

Santoso, U., S. Ohtani and K. Tanaka. 2000. Tuchung leaf meal supplementation reduced an increase in lipid accumulation of chickens stimulated by dietary cholesterol. Asian-Australas. J. Anim. Sci. 13:1758-1763.

Santoso, U. and Sartini. 2001. Reduction of fat accumulation in broiler chickens by Sauropus androgynus (katuk) leaf meal supplementation. Asian-Australas. J. Anim. Sci. 14:346-350.

Santoso, U., J. Setianto and T. Suteky. 2005. Effects of Sauropus androgynus (katuk) extract on egg production and lipid metabolism in layers. Asian-Australas. J. Anim. Sci. 18:364-369.

Santoso, U., Kususiyah and Y. Fenita. 2010a. The 
effect of Sauropus androgynus extract and lemuru oil on fat deposition and fatty acid composition of meat in broiler chickens. J. Indonesian Trop. Anim. Agric. 35:48-54.

Santoso, U., Kususiyah, Y. Fenita, S. Winarsih and A.M.H. Putranto. 2010b. Pengaruh suplementasi ekstrak daun daun plus tepung kunyit pada pakan broiler berlemak tinggi terhadap kualitas karkas dan berat organ dalam. Jurnal Sain Peternakan Indonesia 5 (2):87-94.

Santoso, U., T. Suteky and Y. Fenita. 2010c. Effect of supplementation of alkaloid and non alkaloid from Sauropus androgynus leaves on egg production and lipid profil in layer chicken. 12:184-189.

Santoso, U., Kususiyah and Y. Fenita. 2013. Effect of Sauropus androgynus leaves extract in fat deposition in broilers fed low containing diets. J. Indonesian Trop. Anim. Agric. 38:176-184.

Santoso, U, Y. Fenita, Kususiyah and I.G.N.G. Bidura. 2015a. Effect of fermented Sauropus androgynus leaves on meat composition, amino acid and fatty acid compositions in broiler chickens. Pak. J. Nutr. 14: 799-807.

Santoso, U., Kususiyah and Suharyanto. 2015b. The effect of Sauropus androgynus leaves extract plus turmeric powder on fat deposition, carcass quality and blood profile in broilers fed low protein diets. J. Indonesian Trop. Anim. Agric. 40: 121-130.

Santoso, U., Y. Fenita and Kususiyah. 2017. The effect of medicinal herb inclusion on hematologic status and blood lipids profiles in broiler chickens. Int. J. Poultry Sci. 16: 415-423.

Santoso, U., Y. Fenita, Kususiyah, O. Widiantoro, and S. Kadarsih. 2018. The effect of medicinal herb on fat deposition, meat composition, amino acid and fatty acid composition of broiler meats. J. Indonesian Trop. Anim. Agric. 43 (1): 54-65.

Smink W., W. J. J Gerrits, R. Hovenier, M. J. H. Geelen, M.W.A. Verstegen and A. C. Beynen. 2010Effect of dietary fat sources on fatty acid deposition and lipid metabolism in broiler chickens. Poultry Sci. 89:2432-2440.

von Schacky, C. and S. Harris. 2007. Cardiovascular benefits of omega-3 fatty acids. Cardiovascular Res. 73: 310-315.

Warditiani, N.K., Milawati and N.M.P. Susanti. 2016. Anti dyslipidemic activity of katuk leaves saponin fraction (Sauropus androgynus (L) Merr) in rats induced with fat-rich diet. Int. Pharm. Pharm. Sci. 8:418420.

Winter, Y., S. Rohrmann, J. Linseisen, O. Lanczik, P.A. Ringleb and T. Back. 2008. Contribution of obesity and abdominal fat mass to risk of stroke and transient ischemic attacks. Stroke. 39: 3145-3151.

Wood, J.D., J. Biely and J.E. Topliff. 1961. The effect of diet, age, and sex on cholesterol metabolism in White Leghorn chickens. Canadian J. Biochem. Physiol. 39(11): 1705-1715.

Yiu, W.F., P.L. Kwan, C.Y. Wong, T. S. Kam, S.M. Chiu, W. Chan and R. Chan. 2011. Attenuation of fatty liver and prevention of hypercholesterolemia by extract of Curcuma longa through regulating the expression of CYP7A1, LDL-Receptor, HO-1, and HMG-CoA reductase. J. Food Sci. 76:H80-H89. 